\title{
A Large Undisturbed Column Method to Study Flow and Transport in Macropores and Fractured Media
}

\author{
Jørgensen, Peter Rene; Mosthaf, Klaus; Rolle, Massimo
}

\section{Published in:}

Ground Water

Link to article, DOI:

10.1111/gwat. 12885

Publication date:

2019

Document Version

Peer reviewed version

Link back to DTU Orbit

Citation (APA):

Jørgensen, P. R., Mosthaf, K., \& Rolle, M. (2019). A Large Undisturbed Column Method to Study Flow and Transport in Macropores and Fractured Media. Ground Water, 57(6), 951-961.

https://doi.org/10.1111/gwat.12885

\section{General rights}

Copyright and moral rights for the publications made accessible in the public portal are retained by the authors and/or other copyright owners and it is a condition of accessing publications that users recognise and abide by the legal requirements associated with these rights.

- Users may download and print one copy of any publication from the public portal for the purpose of private study or research.

- You may not further distribute the material or use it for any profit-making activity or commercial gain

- You may freely distribute the URL identifying the publication in the public portal

If you believe that this document breaches copyright please contact us providing details, and we will remove access to the work immediately and investigate your claim 


\section{A Large Undisturbed Column Method to Study Flow and Transport in Macropores and Fractured Media}

Peter R. Jørgensen

Corresponding Author: GEOZ ApS, Klintebakken 9, DK-3520 Farum, Denmark, geozdk@gmail.com.

Klaus Mosthaf

DTU Environment, Technical University of Denmark, Bygningstorvet, 2800, Kgs. Lyngby, Denmark, klmos@env.dtu.dk and

Geological Survey of Denmark and Greenland, Øster Voldgade 10, 1350 Copenhagen, Denmark.

Massimo Rolle

DTU Environment, Technical University of Denmark, Bygningstorvet, 2800, Kgs. Lyngby, Denmark, masro@env.dtu.dk.

Conflicts of interest: None.

Key words: Large Undisturbed Column, fractures and macropores, preferential flow and transport, groundwater contamination, clayey till, modeling

\section{Article Impact Statement}

Illustration, discussion and modeling interpretation of a unique method to investigate flow and transport in macropores and fractured media

This article has been accepted for publication and undergone full peer review but has not been through the copyediting, typesetting, pagination and proofreading process which may lead to differences between this version and the Version of Record. Please cite this article as doi: $10.1111 /$ gwat.12885 


\begin{abstract}
Intact soil columns can bridge the gap between field studies and idealized laboratory investigations of flow and transport in macropores and fractured media. However, the value of intact column studies is often hampered by shortcomings such as lack of column intactness, small column size, and column rim flow, which can cause serious artifacts and hamper system understanding. The flexible-wall pressurized Large Undisturbed Column (LUC) method minimizes these limitations and is a valuable approach to analyze fluid flow and solute transport in macroporous and fractured geological formations. The method investigates subsurface processes in complex media, mimicking in situ conditions and facilitating the control of system boundary conditions including effective stress. In recent years, considerable experience has been gained through different applications of the LUC approach. Modeling tools have also been developed for a detailed interpretation of flow and transport processes in LUC systems. This paper describes the steps of the LUC method from column excavation in the field to experimental setup in the laboratory. The description encompasses the key features of the sampling of large undisturbed columns in field excavations, the laboratory setup, the procedure for hydraulic and transport experiments, as well as practical challenges and potential issues during operation of an LUC system. Application examples with a fully 3-D numerical model of LUC tracer experiments are also presented to illustrate the quantitative interpretation of transport processes in macroporous clayey tills.
\end{abstract}




\section{Introduction}

Controlled laboratory experiments in porous media are essential to investigate flow and contaminant transport in the subsurface (Werth et al. 2010; Rolle et al. 2013a; Haberer et al. 2014, 2015; Ye et al. 2015). Such experiments often need to include natural geological heterogeneity and preferential flow pathways, e.g., fractures, earthworm holes and root channels, because these often control contaminant transport in otherwise low permeability geological units such as clays, shales and limestones (Grisak et al. 1980; Harrison et al. 1992; Parker et al. 1997; Klint and Gravesen 1999; Berkowitz 2002; Jørgensen et al. 2004b; Cherry et al. 2006; Rosenbom et al. 2008; Kessler et al. 2012, 2013; Libby and Robbins 2014; Broholm et al. 2016). Well-controlled laboratory studies are essential to complement field investigations, because in the latter it can be difficult or even impossible to establish, control, and manipulate boundary conditions. This typically leads to large degrees of freedom for the evaluation of obtained contaminant transport data and, consequently, to large uncertainties of derived key-values for the description of masstransport processes. However, such values are essential for modeling, understanding, and predicting the fate and transport of pollutants in complex subsurface environments (Wildenschild et al. 1994; Neuman 2005; Blessent et al. 2009; Rosenbom et al. 2009; Chambon et al. 2010; Chapman et al. 2013; Mosthaf et al. 2018). Moreover, field experiments typically yield average or bulk properties of flow systems, which makes it difficult to differentiate the impact of individual flow paths with different origins and spatial occurrences in geological formations (e.g., desiccation and tectonic fractures, biopores, fracture channels and textural heterogeneities). Yet, such information is crucial to 
understand contaminant transport and to develop more efficient groundwater protection strategies.

Controlled boundary conditions can be established in the laboratory using column experiments (Grisak et al. 1980; O’Hara et al. 2000; Jørgensen et al. 2002). In these setups, different types of preferential flow paths can be represented, and associated flow and contaminant migration can be manipulated and closely monitored under well-defined pressure and temperature conditions close to natural, in situ conditions. Thus, coupled parameter values of flow paths and contaminant migration can be determined (Jørgensen et al. 2004a). Conventional intact column experiments, however, typically suffer from a number of limitations and shortcomings, which may lead to artifacts and low experimental reproducibility, thereby undermining the reliability of such studies. Common pitfalls are: (i) small column size, which prevents an adequate representation of soil heterogeneities and structures governing flow and transport, e.g., macropores and textural heterogeneity, (ii) artificial flow along column rims, (iii) disturbance of columns and their internal structures during sampling and laboratory procedures, and (iv) infeasibility of reproducing the in situ confining soil stress and temperature occurring at the different depths where the intact column samples were collected.

The pressurized Large Undisturbed Colum (LUC) method presented in this article facilitates investigation of flow and transport dynamics in macroporous soils and fractured soft rock at a representative intermediate scale, between the small scale of common laboratory experiments and the large scale of field investigations. The LUC approach minimizes the shortcomings of conventional intact column experiments mentioned above. 
The method employs large cylindrical monoliths to conduct hydraulic tests and solute transport experiments. The large diameter allows to include representative features of preferential flow such as fractures or fracture networks. The careful excavation of the columns preserves the natural geology and allows the experimental conditions to be controlled, e.g., by pressurizing the column and controlling flow rates and temperature conditions. The method has been successfully applied in multiple studies to improve the understanding and the characterization of solute mass transport and multi-phase flow in macroporous media (e.g., Jørgensen and Spliid 1993, 2016; Hinsby et al. 1996; Jensen et al. 1998, 1999, Jørgensen et al. 1998a; b; Broholm et al. 1999; O’Hara et al. 2000). LUC studies provided new insights into fracture flow paths and contributed to an improved description of mass-transport processes. The detailed experimental approach also allowed the quantification of key parameters controlling water flow and solute transport in macropores and fractured media. For example, Jørgensen et al. (2002) determined the variation of hydraulic fracture apertures related to observed patterns of infiltrated dye tracers, showing that fracture flow and groundwater risk due to migration of pesticides were controlled by large aperture abandoned root channels along the fractures, whereas the fractures themselves consistently had small apertures and contributed only marginally to groundwater recharge and contaminant fluxes. Such experimental findings have contributed to an ongoing paradigm shift in the conceptual understanding of fractures as main contributors to the risk of groundwater contamination by pesticides.

LUC experiments also provide high-quality datasets that are essential for testing the ability of different numerical modeling concepts to correctly simulate macropore solute fluxes 
into aquifers in response to various flow rates. For instance, Jørgensen et al. (2004a; b) and Blessent et al. (2014), generated LUC datasets of solute mass transport with different flow rates and used the experimental observations to test flow and transport models and their capability to capture the variations of the solute mass transfer between macropores and matrix in the LUC columns.

There has been significant development of the LUC method through different application studies; however, its thorough description and explanation have not yet been provided. In this paper, we illustrate the LUC method and provide a detailed description of column excavation, preparation, sampling, and laboratory procedures. We discuss technical aspects that need to be considered both in the field and in the laboratory, as well as potential shortcomings and precautions to mitigate and/or avoid them. We also present an example with quantitative model-based interpretation of an LUC experiment. The example is based on an accurate representation of the geometry and boundary conditions of the LUC setup and on 3-D simulations of flow and transport processes in macropores and fractured media.

\section{The LUC Method}

The LUC method uses a large flexible-wall permeameter setup with an undisturbed soil column $(0.5 \mathrm{~m}$ in diameter and $0.5 \mathrm{~m}$ in length), as shown in Figure 1 . The soil column isinstalled in the flexible-wall permeameter, where the pressure and temperature conditions in the column can be controlled during flow and transport experiments (Figure 1).

The column is sealed against contact with the pressurized water in the permeameter with a prefabricated flexible tube-shaped polyurethane membrane, which is glued to the column 
by filling a polyurethane fluid along the column rims to prevent rim flow along the membrane (Figure 1). The column is held in place at both ends by stainless steel endplates that fit into the membrane, which is molded tightly around the shape of the endplate with the help of clamps. The system is pressurized by submerging the sealed column in the permeameter fluid (usually water). Pressure can be controlled with an external compressor or the hydrostatic level in a reservoir tank. The pressure in the cell containing the permeameter fluid is transmitted to the soil sample through the flexible polyurethane membrane. The permeameter temperature is controlled by circulating cooling liquid through a copper coil installed inside the permeameter. Alternatively, cooling may be achieved by housing the completed permeameter in a cold room (O'Hara et al. 2000).

The sealed column interior is connected through four ports in each plate to the exterior of the permeameter by stainless steel influent and effluent tubings. The tubings allow control of the flow and sampling at the inlet and outlet of the column. The four ports in each endplate are equipped with Swagelock ${ }^{\mathrm{TM}}$ fittings, stainless steel fittings, tubings $(0.12$ inch outer diameter, 0.02 inch wall thickness), and dead-end tubes. The latter are used for the release of gas potentially accumulating from degassing or from biological activity in the soil column, as well as for the installation of monitoring devices (e.g., for monitoring the hydraulic head gradient along the column's height). The column end-surfaces and the stainless steel endplates are separated by two layers of stainless steel meshes $(0.125 \mathrm{~mm}$ mesh) to effectively distribute the water between the end-surfaces of the column and the endplate ports, and to minimize the water volume (approximately $75 \mathrm{ml}$ ) between the column end-surfaces and the endplates. 
The column is usually installed in an upside down position and hydraulic experiments are carried out by injecting water through the four ports at the bottom endplate (watersaturated experiments). This facilitates flushing of entrapped air from the top of the column, while the flow is analog to vertical downward flow in the natural setting from where the LUC was sampled.

Field procedure of column sampling

The column sampling in the field is carried out by excavating a $1.5 \mathrm{~m} \times 1.5 \mathrm{~m} \times 1 \mathrm{~m}$ pedestal from the soil surface or in an excavation. Then, the pedestal is roughly shaped into the dimensions of the final column. To avoid disturbances of the column, the sampling (from the point where the initial pedestal has been excavated) should be carefully carried out by using hand tools only. The use of machine force may cause disturbances of macopore structures, create grooves from stones being pushed along the column sides, and potentially generate artificial fractures in the column. This should be avoided since even small fracture aperture disturbances can result in very large responses to the flow due to the cubic relation between fracture aperture and fracture flow (Snow 1969). On the top of the pedestal, a sampling cylinder (diameter $0.52 \mathrm{~m}$, length $0.7 \mathrm{~m}$ ) is placed with a sharp removable cutting shoe at its lower end, which defines the final diameter $(0.5 \mathrm{~m})$ of the cylindrical soil column (Figure 2a). The sampling cylinder is gently pressed vertically downward by adding weights (maximum $30-50 \mathrm{~kg}$ ) on top of the sampling cylinder.

Concurrently with the column sampling cylinder slowly moving downward, excess soil material along the cutting shoe is continuously removed with hand tools to reduce the pressure imposed onto the column. The vertical position of the sampling cylinder is 
continuously controlled with levelers (Figure 2a) to minimize skew and irregularities in the column. When the sampling cylinder has been lowered to the maximum depth required (column length of ca. $0.7 \mathrm{~m}$ ), it is removed (Figure 2b), while the cutting shoe is left for removal after the column has been detached.

At this stage, a prefabricated flexible polyurethane membrane (diameter $0.5 \mathrm{~m}$, length 0.5 $\mathrm{m}$, and thickness $3 \mathrm{~mm}$ ) is pulled over the exposed column (Figure 2c) and fluid polyurethane is poured between the column and the membrane to prevent rim flow. A steel split cylinder is then placed around the rubber membrane and tightened by metal clamps to allow transport of the sample (Figure 2d). After tightening the clamps, excess polyurethane fluid between the column and the flexible membrane is discplaced and removed. The column should rest overnight to allow the fluid polyurethane to glue together with the membrane by hardening and adhering to the soil matrix (i.e., the fluid penetrates about 1-2 $\mathrm{mm}$ into the soil matrix, Figure 1). This procedure makes the column rim impermeable, yet flexible enough to respond to the imposed pressure when the column is placed in the LUC permeameter setup. After the fluid polyurethane has solidified, the column is detached from the geological formation and equipped with transport end-caps (Figure 2d) for transportation to the laboratory.

Laboratory preparation, installation procedures, and tests

In the laboratory, the end-surfaces of the columns are carefully leveled, chipped, and vacuumed to remove any smearing and loose soil particles caused by excavation, which could block the macropores. The clean end-surfaces are covered with two layers of stainless steel meshes $(0.125 \mathrm{~mm}$ mesh $)$. After installing the column endplates, the interior 
of the column is subjected to a vacuum of -30 to $-60 \mathrm{kPa}$ through the column inlet/outlet ports. The vacuum allows the steel split cylinder to be removed and the column to be handled with minimal risk of disturbing the column interior. With the split transport cylinder removed, the column is installed in the permeameter and connected to the stainless steel influent and effluent lines (Figure 1). The cell pressure can then be adjusted to reproduce in situ conditions. To this end, the cell pressure has to account for both the pressure exerted by the fluid and the soil material (overburden) (Freeze and Cherry 1979). For a water-saturated soil, this can be estimated as $P_{\text {cell }}=\rho_{\mathrm{s}}(1-\phi) g H_{\mathrm{s}}+\rho_{\mathrm{w}} \phi g h$, with the cell pressure $P_{\text {cell }}$, the density of the soil material $\rho_{s}$, the total porosity $\phi$, the water density $\rho_{w}$, the standard gravity $g$, the hydraulic head $h$ and the height of the overburden measured from the bottom of the column $H_{s}$.

Both hydraulic tests and transport experiments can be conducted in the LUC setup. The hydraulic tests investigate the physical and hydrodynamic parameters controlling water flow in the macropore and fractured media. Figure 3 shows the outcomes of hydraulic tests performed on an LUC from a clayey till formation over a range of flow rates and hydraulic gradients. The flow rate in this fractured clayey till column was linearly proportional to the hydraulic gradient and allowed determination of the effective hydraulic conductivity for the soil column. For this clayey till with small-aperture fractures, an effective hydraulic conductivity of $1.8 \times 10^{-8} \mathrm{~m} / \mathrm{s}$ was determined from the bulk flow of the LUC and a matrix hydraulic conductivity in the range of $2 \times 10^{-9}$ to $2 \times 10^{-8} \mathrm{~m} / \mathrm{s}$ from subcores of the LUC. These values yielded the representative average hydraulic aperture of the fractures in the column through the cubic law governing the flow along these preferential flow paths. An 
activation of additional flow paths due to an increased hydraulic gradient was not observed during the experiments in this column setup.

Flow-through transport experiments allow the investigation of transport processes through measurements of solute breakthrough at the outlet. The LUC setup facilitates the investigation of the interactions and solute mass transfer between preferential flow paths and low-permeability matrix in complex geologic media. Examples of transport experiments and their model-based interpretation are offered in Section 3.

After the flow and transport tests, the column can be opened and dissected in order to inspect the porous and fractured medium. Injection of a dye tracer (e.g., brilliant blue, Flury and Flühler 1995) into the column prior to the segmentation facilitates identification and mapping of the major transport pathways (macropores/fractures/fracture channels) and sheds light on the matrix diffusion behavior. The infiltrated dye tracer can also reveal conductive fracture segments and flow channeling between the fracture walls. Mapping macropores and fractures at different depths within the LUC allows an understanding of the geometry, distribution and connectivity of these important preferential flow and transport pathways (O'Hara et al. 2000). Hydraulic properties of the matrix at different spatial locations can be determined by subcoring the LUC and performing porosity and permeability tests at the scale of the samples. Such investigations are also useful for refining the description of the geometry and physical properties of the domains used for modeling the LUC experiments. 


\section{Column representativeness}

The LUC method allows flow to be captured through a relatively large domain with discrete fractures, including their natural distribution, connectivity, and aperture variability (O’Hara et al. 2000; Jørgensen et al. 2002). Injected tracers and chemicals can be transported through fractures and macropores and exchange freely (by diffusion and advection) with relatively large matrix blocks, avoiding interference with the column boundaries and mimicking natural solute migration. The capability of closely representing the natural transport behavior in complex macropores and fractured media is a key feature of the LUC systems. Careful attention should be paid to preserving this important characteristic of the setup; therefore, the effects of operations and processes that can alter column representativeness should be minimized. For instance, there is a high risk of disturbing fractures and biopores mechanically by pressure release and external forces during both field column sampling and laboratory operations, which must be conducted with great care. Testing intactness and physical stability of LUC columns is essential in assessing the quality of the collected sample and its suitability for performing detailed flow and transport experiments. For this purpose, the water-saturated effective hydraulic conductivity $(K)$ can be measured first at the permeameter pressure that was used for keeping the columns undisturbed during transport and installation in the permeameter and, thereafter, at the in situ confining stress representing the natural depth at which the column was sampled. Observations from LUC experiments showed negligible differences in $K$ values between the two applied permeameter pressures, which indicate that the columns in these experiments were coherent and undisturbed since new cracks or breaking up of 
existing fractures would likely respond to the pressure changes and thereby cause significant changes in the effective $K$ values. Furthermore, another useful test is the longterm assessment of column stability. Data from a series of LUC experiments revealed less than $2 \%$ variation in $K$ values over approximately one year (Jørgensen et al. 2004a). Intactness of the columns can be further tested when the columns are dissected, after the injection of a dye tracer (e.g., brilliant blue) solution. The dye tracer distribution in the complex geologic medium facilitates visualization of the major transport pathways such as fractures and macropores, which can be inspected to determine if they are natural or if they were generated during column excavation and preparation. For instance, the lack of any chemical alternation or secondary mineral precipitation (Corrigan et al. 2001) in a subset of clearly dyed fractures suggests that they are artificially created fractures.

Precautions should also be adopted to avoid rim flow. As mentioned above, this is prevented by the special technique of molding together the column membrane and the soil column rim with polyurethane. However, it is good practice to test the occurrence of rim flow at the end of the flow-through experiments when the LUC setup is dismantled and the column can be dissected for inspection. Testing for rim flow is carried out by infiltration of a dye tracer before unwrapping the flexible membrane from the column after the experiments Rim flow, will be clearly visible from dye tracer on the surface of the membrane. This has only been observed in a few cases when the influent hydraulic pressure was accidentally kept at a significantly higher level than the pressure in the permeameter cell. 
Finally, gas accumulation can complicate characterization. Buildup of gas can occur in columns with high microbial activity, and water flow can be partially blocked by accumulating gas. This would bias the experimental results and could, for example, lead to incorrect (too low) values of effective hydraulic conductivity $(K)$. Some experiments with LUCs revealed decreasing $K$ vales over the course of the experiment due to the accumulation of gas along the top and bottom column end-plates from soil microbial activity. The effects of such gas accumulation can be minimized with a short flow interruption and flushing accumulated gas through the valves installed on the influent and effluent tubing (Figure 1). Previous LUC experiments have shown that in such cases the initial column hydraulic conductivity could be re-established after these operations. The extracted gas may also be collected for microbiological studies. However, flow interruptions for flushing accumulated gas may not be feasible in all types of LUC experiments. In such cases, a constant flow rate in the columns can be maintained by using a peristaltic or infusion pump (Jørgensen et al. 2004b). Alternatively, reduction of gas was successfully achieved by inhibiting microbial activity through addition of sodium azide $\left(\mathrm{NaN}_{3}\right)$ to the influent solution (e.g., at $0.02 \%$ by weight as by Broholm et al. 1999).

\section{3-D modeling of LUC systems}

Numerical simulations can facilitate a detailed, quantitative interpretation of LUC experiments. Flow and transport models with different approaches, dimensionality, and progressively increasing levels of complexity have been proposed to simulate LUC 
systems (Jørgensen et al. 2004a; Blessent et al. 2014). Here, we present a 3-D numerical model that allows detailed investigations of LUC experiments. The model simulates flow and transport processes through fractures and matrix during LUC tests. It allows the analysis of the influence of different experimental settings and operations and can serve as tool to design, optimize and interpret LUC experiments. As an illustrative example, we applied the model to the bromide tracer tests carried out by Jørgensen et al. (2004a). The flow-through experiments were performed using variable flow rates (including flow interruptions) with a constant tracer (bromide) concentration of $100 \mathrm{mg} / \mathrm{L}$ in the influent. The modeling approach consists of a discrete-fracture model (DFM) for flow and transient transport. Fractures are resolved as 2-D planes with distinct properties embedded in the 3D porous matrix (clayey-till). Fractures and matrix are coupled by the continuity of primary variables (hydraulic head and concentration for flow and transport, respectively) and of the fluxes at the fracture-matrix interface. Darcy's law is used to calculate a steadystate flow field in the fractures and the matrix of the LUC and the hydraulic conductivities of the fractures are calculated with the cubic law (Snow 1969). Here, we consider fractures as the void space between parallel flat and smooth plates. If variations of local fracture aperture, tortuosity and roughness are known, they can be taken into account by using the modified local cubic law (Wang et al. 2015). The transport equation including diffusive and advective transport is solved throughout the model domain (fractures and matrix).

The 3-D flow and transport model was implemented in COMSOL Multiphysics ${ }^{\circledR}$ with the geometry accurately reproducing the LUC experimental setup and model parameters described by Jørgensen et al. (2004a); see summary in Table 1. The experimental setup 
was conceptualized to consist of three parallel and equally spaced fractures, which were embedded in the 3-D model domain to represent preferential flow paths in the LUC medium. The flow model was manually calibrated to the experiments by varying the hydraulic aperture of the three fractures while keeping the hydraulic matrix conductivity constant (Table 1), until the simulated hydraulic head gradients fit the measured ones at the flow rates used in the experiments. This procedure yielded a hydraulic fracture aperture of 94.6 $\mu \mathrm{m}$ for the three fractures. With the hydraulic parameters fixed, the transport model was manually calibrated to the tracer breakthrough curve by variation of the matrix tortuosity. Other parameters were kept constant at the values presented by Jørgensen et al. (2004b).

Table 1: Model parameters, based on Column 3 in the paper by Jørgensen et al. (2004a).

\begin{tabular}{ll}
\hline Parameter & Value \\
\hline Hydraulic matrix conductivity $(K)$ & $5 \times 10^{-10} \mathrm{~m} / \mathrm{s}$ \\
Porosity $(n)$ & 0.31 \\
Tortuosity $(\ddot{A})$ & 0.20 \\
Aperture (2b) & $94.6 \mu \mathrm{m}$ \\
Fracture spacing $(2 B)$ & $17 \mathrm{~cm}$ \\
$\begin{array}{l}\text { Aqueous diffusion coefficient } \\
\text { bromide }\left(D_{\mathrm{w}}\right)\end{array}$ & $2 \times 10^{-9} \mathrm{~m}^{2} / \mathrm{s}$ \\
$\begin{array}{l}\text { Aqueous diffusion coefficient } \\
\text { bromide }\left(D_{\mathrm{w}}\right)\end{array}$ & $0.4 \times 10^{-9} \mathrm{~m}^{2} / \mathrm{s}$ \\
\hline
\end{tabular}

Figure 4a shows the 3-D setup with three equidistant, parallel fractures in a cylinder with a diameter of $0.5 \mathrm{~m}$ and a height of $0.5 \mathrm{~m}$, representing the clayey till column. The tracer 
enters the domain through the four circular inlet ports at the bottom of the model domain (column is installed upside down, so the flow is from the original sample top to bottom) and leaves through four outlet ports at the top of the column. To obtain a realistic representation of the LUC setup and to distribute the flow according to the hydraulic conductivity at the inflow surface of the soil column, an inflow volume was included, which mimics the effect of the stainless steel meshes (spacers) between the inflow end plate and the soil column (Figure 1). The same was done at the outflow side of the soil column.

Figure $4 \mathrm{~b}-\mathrm{f}$ show the simulated evolution of the bromide concentration in the LUC over a period of 20 days. The tracer is first transported from the inlet ports along the steel meshes and diffuses partly into the matrix (Figure 4b). When it reaches a fracture, it is transported by the relatively fast fracture flow, while continuing to diffuse into the matrix (Figures $4 \mathrm{~b}$ d). After approximately 6.7 days (14.8 L of injected tracer solution), the tracer injection was stopped and the LUC was flushed with pure water applying the same flow rate (Figure 4d). The flushing water flowing through the fractures has a lower concentration, hence the bromide accumulated in the pores of the low-permeability matrix diffuses back into the fractures as well as deeper into the matrix (Figure 4e-f).

The measured and simulated outflow concentrations are plotted in Figure 5a. The tracer arrives very quickly at the outlet of the LUC, due to the flow through the major connected preferential transport paths. Upon cessation of tracer injection, pure water was flushed through the column, the measured concentrations at the outlet start to decrease and the breakthrough curve revealed tailing behavior due to the diffusive mass-transfer of bromide 
from the matrix to the fractures. The simulated concentrations were determined as fluxaveraged concentrations at the four outlet ports and matched the experimental data well. The model captured fast transport through the fractures, the early arrival of the tracer at the outlets, and measured peak concentrations. It also correctly reproduced the pattern of the experimental breakthrough curve with the early arrival of the solutes through the preferential flow paths followed by long tailing after stopping tracer injection.

The model was also applied to another LUC experiment, described by Jørgensen et al. (2004a). In this case a sequence of different flow rates was employed, thus creating dynamic flow conditions, rates between 4.8 and $24.9 \mathrm{~mm}$ /day were applied with continuous injection of the bromide solution. The impact of the flow rates on the breakthrough concentrations is evident in Figure $5 \mathrm{~b}$ and shows the capability of the 3-D discrete-fracture model to reproduce solute transport with fracture-matrix interaction in the clayey till medium under dynamic flow conditions.

To further assess the influence of flow rate on mass transfer between fractures and matrix, the model calibrated to the constant flow rate was then used with different flow rates using the same LUC setup simulating the single injection-flushing cycle. At higher flow rates, advective transport through the fractures dominated, while the influence of matrix diffusion was more pronounced at lower flow rates (Figure 6). For example, at a fast flow rate of $50 \mathrm{~mm} /$ day, the initial breakthrough concentration increase was steep due to the dominant contribution of advection through preferential flow paths. At the end of the injection phase, a peak concentration of ca. $90 \%$ of the injected concentration is reached. As soon as flushing was initiated (after injecting $20 \mathrm{~L}$ of tracer solution), the concentration 
decreased sharply. In contrast, for a slow flow rate of $0.2 \mathrm{~mm} /$ day the breakthrough curve was remarkably smoother. The arrival time of the peak concentration was delayed and occured after the tracer injection phase. Also, the values of the tracer concentration were lower (i.e., peak concentration ca. 55\% of injected), showing a more significant degree of dilution of the solute plume under these slow flow-through conditions (Rolle and Kitanidis 2014; Chiogna and Rolle 2017).

The different curves, spanning a representative range of flow rates, illustrate well the relative importance of advection and diffusion and show how the interplay between these important mass-transfer processes in complex macropores and fractured geologic media affects the solute breakthrough. This example also highlights other important features of the 3-D model: the simulations can be used as a design tool to plan and optimize LUC experiments, as well as to perform numerical experiments, e.g., to test hypotheses and investigate cause-effect relationships.

\section{Conclusion and outlook}

The LUC method is a unique, elaborate experimental technique for the study of flow and transport processes through undisturbed soil columns under in situ stress and provides reliable data on fluid flow and solute mass transport in complex macropores and fractured media. The method benefits from the possibility of controlling the boundary conditions during the large intact column experiments, which significantly reduces the uncertainty of flow and transport results compared to field experiments. We have described the key procedures of the method from the field sampling of intact cores to the laboratory 
operations of the LUC setup. We have also discussed the main technical challenges of the setup and the precautions, tests, and actions to adopt to minimize the effects on the representativeness of large undisturbed columns. Furthermore, we illustrated the value of combining LUC experiments with 3-D numerical modeling. The model-based assessments of LUC data facilitates analysis and quantification of transport processes and their interactions in geologic materials with complex structure and heterogeneity such as clayey tills with both macropores/fractures and a low-permeability matrix.

The LUC method is appropriate for geological media such as glacial tills, shales and limestones. These formations are widespread in the shallow subsurface and are of primary importance in groundwater flow systems. Thus, the results and insights from LUC experiments have the potential to improve hydrogeologic understanding of a wide range of macroporous geological formations, which is of pivotal importance for risk assessment and groundwater protection. The main focus of LUC studies has been the investigation of physical heterogeneity and transport processes in saturated porous media. Future research will likely address reactive transport and more complex biogeochemical systems. Further development of the LUC method will include: (i) transport with sorption and biodegradation of organic contaminants (including pesticides, pharmaceuticals, and micropollutants) in macroporous geologic formations (Rosenbom et al. 2014; Yu et al. 2018); (ii) flow and transport in macropores and fractured media under unsaturated conditions (Mortensen et al. 2004); (iii) transport of inorganic contaminants and colloids (McKay et al. 1993; Cohen and Weisbrod 2018; James et al. 2018); (iv) transport of major cations and anions with electrostatic interactions within the pore water and at the 
solid/solution interface (Rolle et al. 2013b; Muniruzzaman et al. 2014); (v) flow and transport of immiscible phases such as chlorinated solvents (Pankow and Cherry 1996; O'Hara et al. 2000); (vi) impact of chemical and combined physico-chemical heterogeneity (Li et al. 2014; Fakhreddine et al. 2016; Battistel et al. 2018), and (vii) microbial metabolism with gas production and determination of efflux gases (Sihota et al. 2018). Experimental advances in the LUC setup will also be paralleled by numerical model development. For instance, in the case of LUC reactive transport experiments in more complex biogeochemical setups, the 3-D discrete-fracture model presented in this study could be developed to include networks of kinetic and equilibrium reactions through a flexible coupling with geochemical databases as recently proposed for porous media (Parkhurst and Wissmeier 2015; Muniruzzaman and Rolle 2016).

\section{Acknowledgements}

The authors wish to thank project students and colleagues involved with the LUC studies and the Danish Geotechnical Institute (now GEO) for having provided facilities and technical support for the early method development. The financial support by the Danish EPA and Dr. Neergaard and Wife Foundation are greatly appreciated. The authors thank Jens Aamand and the colleagues in the CLAYFRAC and PESTPORE projects for fruitful discussions, Riccardo Sprocati for help with the graphical illustration of the LUC setup, and Chloe Lanters for proof-reading the manuscript. 


\section{References}

Battistel, M., M. Muniruzzaman, F. Onses, J. Lee and M. Rolle. 2018. Reactive Fronts in Chemically Heterogeneous Porous Media: Experimental and Modeling Investigation of Pyrite Oxidation. Applied Geochemistry $100 \quad$ (2018): 77-89. https://doi.org/10.1016/J.APGEOCHEM.2018.10.026.

Berkowitz, B. 2002. Characterizing Flow and Transport in Fractured Geological Media: A Review. Advances in Water Resources 25 (8-12): 861-84. https://doi.org/10.1016/S0309-1708(02)00042-8.

Blessent, D., P. R. Jørgensen and R. Therrien. 2014. Comparing Discrete Fracture and Continuum Models to Predict Contaminant Transport in Fractured Porous Media. Groundwater 52 (1): 84-98. https://doi.org/10.1111/gwat.12032.

Blessent, D., R. Therrien and K. MacQuarrie. 2009. Coupling Geological and Numerical Models to Simulate Groundwater Flow and Contaminant Transport in Fractured Media. Computers \& Geosciences 35: 1897-1906. https://doi.org/10.1016/j.cageo.2008.12.008.

Broholm, K., P. R. Jørgensen, A. B. Hansen, E. Arvin and M. Hansen. 1999. Transport of Creosote Compounds in a Large, Intact, Macroporous Clayey till Column. Journal of Contaminant Hydrology 39: 309-29.

Broholm, M. M., G. S. Janniche, K. Mosthaf, A. S. Fjordbøge, P. J. Binning, A. G. Christensen, B. Grosen et al. 2016. Characterization of Chlorinated Solvent Contamination in Limestone Using Innovative FLUTe Technologies in Combination with Other Methods in a Line of Evidence Approach. Journal of Contaminant 
Hydrology 189: 68-85. https://doi.org/10.1016/j.jconhyd.2016.03.007.

Chambon, J. C., M. M. Broholm, P. J. Binning and P. L. Bjerg. 2010. Modeling MultiComponent Transport and Enhanced Anaerobic Dechlorination Processes in a Single Fracture-Clay Matrix System. Journal of Contaminant Hydrology 112 (1-4): 77-90. https://doi.org/10.1016/j.jconhyd.2009.10.008.

Chapman, S. W., B. L. Parker, J. A. Cherry, S. D. McDonald, K. J. Goldstein, J. J. Frederick, D. J. ST. Germain, D. M. Cutt and C. E. Williams. 2013. Combined MODFLOW-FRACTRAN Application to Assess Chlorinated Solvent Transport and Remediation in Fractured Sedimentary Rock. Remediation Journal 23 (3): 7-35. https://doi.org/10.1002/rem.21355.

Cherry, J. A., B. L. Parker, K. R. Bradbury, T. T. Eaton, M. B. Gotkowitz, D. J. Hart and M. A. Borchardt. 2006. Contaminant Transport through Aquitards: A State-of-theScience Review. Denver.

Chiogna, G. and M. Rolle. 2017. Entropy-Based Critical Reaction Time for MixingControlled Reactive Transport. Water Resources Research 53 (8): 7488-98. https://doi.org/10.1002/2017WR020522.

Cohen, M. and N. Weisbrod. 2018. Transport of Iron Nanoparticles through Natural $\begin{array}{llll}\text { Discrete } & \text { Fractures. } & \text { Water }\end{array}$ https://doi.org/10.1016/j.watres.2017.11.019.

Corrigan, C. A., H. E. Jamieson and V. H. Remenda. 2001. Fracture Wall Cements and Coatings from Two Clayey till Aquitards. Ground Water 39 (5): 786-94.

Fakhreddine, S., J. Lee, P. K. Kitanidis, S. Fendorf and M. Rolle. 2016. Imaging 
Geochemical Heterogeneities Using Inverse Reactive Transport Modeling: An Example Relevant for Characterizing Arsenic Mobilization and Distribution. $\begin{array}{llll}\text { Advances } & \text { in } & \text { Water } & \text { Resources }\end{array}$ https://doi.org/10.1016/j.advwatres.2015.12.005.

Flury, M. and H. Flühler. 1995. Tracer Characteristics of Brilliant Blue FCF. Soil Science $\begin{array}{llllll}\text { Society } & \text { of } & \text { America } & \text { Journal } & 59 & \text { (1): }\end{array}$ https://doi.org/10.2136/sssaj1995.03615995005900010003x.

Freeze, R. A. and J. A. Cherry. 1979. Groundwater. Prentice-Hall. https://findit.dtu.dk/en/catalog/2304905336.

Grisak, G., J. Pickens and J. Cherry. 1980. Solute Transport through Fractured Media: 2. Column Study of Fractured Till. Water Resources Research 16 (4): 731-39. http://onlinelibrary.wiley.com/doi/10.1029/WR016i004p00731/full.

Haberer, C. M., O. A. Cirpka, M. Rolle and P. Grathwohl. 2014. Experimental Sensitivity Analysis of Oxygen Transfer in the Capillary Fringe. Groundwater 52 (1): 37-49. https://doi.org/10.1111/gwat.12028.

Haberer, C. M., M. Rolle, O. A. Cirpka and P. Grathwohl. 2015. Impact of Heterogeneity on Oxygen Transfer in a Fluctuating Capillary Fringe. Groundwater 53 (1): 57-70. https://doi.org/10.1111/gwat.12149.

Harrison, B., E. A. Sudicky and J. A. Cherry. 1992. Numerical Analysis of Solute Migration through Fractured Clayey Deposits into Underlying Aquifers. Water Resources Research 28 (2): 515-26. https://doi.org/10.1029/91WR02559.

Hinsby, K., L. D. Mckay, P. R. Jørgensen, M. Lenczewski and C. P. Gerba. 1996. Fracture 
Aperture Measurements and Migration of Solutes, Viruses, and Immiscible Creosote in a Column of Clay-Rich Till. Ground Water 34 (6): 1065-75.

James, S. C., L. Wang and C. V. Chrysikopoulos. 2018. Modeling Colloid Transport in Fractures with Spatially Variable Aperture and Surface Attachment. Journal of Hydrology 566 (September): 735-42. https://doi.org/10.1016/j.jhydrol.2018.09.047.

Jensen, M. B., H. C. B. Hansen, P. R. Jørgensen and J. Magid. 1999. Leaching of Phosphate in Structured Soil - a Two Step Process. Nordic Hydrology 30 (4/5): 36178.

Jensen, M. B., P. R. Jørgensen, H. C. B. Hansen and N. E. Nielsen. 1998. Biopore Mediated Subsurface Transport of Dissolved Orthophosphate. Journal of Environmental Quality 27 (5): 1130.

Jørgensen, P. R., K. Broholm, T. O. Sonnenborg and E. Arvin. 1998a. DNAPL Transport through Marcroporous, Clayey till Columns. Ground Water 36: 651-60.

Jørgensen, P. R., T. Helstrup, J. Urup and D. Seifert. 2004a. Modeling of Non-Reactive Solute Transport in Fractured Clayey till during Variable Flow Rate and Time. Journal of Contaminant Hydrology $68 \quad$ (3-4): 193-216. https://doi.org/10.1016/S0169-7722(03)00146-3.

Jørgensen, P. R., M. Hoffmann, J. P. Kistrup, C. Bryde, R. Bossi and K. G. Villholth. 2002. Preferential Flow and Pesticide Transport in a Clay-Rich till / : Field, Laboratory, and Modeling Analysis. Water Resources Research 38 (11). https://doi.org/10.1029/2001WR000494.

Jørgensen, P. R., L. D. Mckay and N. H. Spliid. 1998b. Evaluation of Chloride and 
Pesticide Transport in a Fractured Clayey till Using Large Undisturbed Columns and Numerical Modeling. Water Resources Research 34 (4): 539-53.

Jørgensen, P. R. and N. H. Spliid. 2016. Accumulation of Pesticides in Anaerobic Clayey Till-Controls and Implications for Groundwater. Groundwater Monitoring \& Remediation, no. 3: 43-53. https://doi.org/10.1111/gwmr.12154. 1993. Mechanisms and Rates of Pesticide Leaching in Shallow Clayey Till. In Integrated Soil and Sediment Research: A Basis for Proper Protection, edited by H.J.P. Eijsackers \& Harmers, 247-53. Kluwer Academic Publishers.

Jørgensen, P. R., J. Urup, T. Helstrup, M. B. Jensen, F. Eiland and F. P. Vinther. 2004b. Transport and Reduction of Nitrate in Clayey till underneath Forest and Arable Land. Journal of Contaminant Hydrology 73 (1-4): 207-26. https://doi.org/10.1016/j.jconhyd.2004.01.005.

Kessler, T. C., A. Comunian, F. Oriani, P. Renard, B. Nilsson, K. E. Klint and P. L. Bjerg. 2013. Modeling Fine-Scale Geological Heterogeneity-Examples of Sand Lenses in Tills. Groundwater $51 \quad$ (5): $\quad 692-705 . \quad$ https://doi.org/10.1111/j.17456584.2012.01015.x.

Kessler, T. C., K. E. S. Klint, B. Nilsson and P. L. Bjerg. 2012. Characterization of Sand Lenses Embedded in Tills. Quaternary Science Reviews 53 (C): 55-71. https://doi.org/10.1016/j.quascirev.2012.08.011.

Klint, K. E. S. and P. Gravesen. 1999. Fractures and Biopores in Weichselian Clayey till Aquitards at Flakkebjerg, Denmark. Nordic Hydrology 30 (4-5): 267-84.

Li, L., F. Salehikhoo, S. L. Brantley and P. Heidari. 2014. Spatial Zonation Limits 
Magnesite Dissolution in Porous Media. Geochimica et Cosmochimica Acta 126: 555-73. https://doi.org/10.1016/j.gca.2013.10.051.

Libby, J. L. and G. A. Robbins. 2014. An Unsteady State Tracer Method for Characterizing Fractures in Bedrock Wells. Groundwater 52 (1): 136-44. https://doi.org/10.1111/gwat.12045.

McKay, L. D., R. W. Gillham and J. A. Cherry. 1993. Field Experiments in a Fractured Clay till 2. Solute and Colloid Transport. Water Resources Research 29 (12): 387990. https://doi.org/10.1029/93WR02069.

Mortensen, A. P., K. H. Jensen, B. Nilsson and R. K. Juhler. 2004. Multiple Tracing Experiments in Unsaturated Fractured Clayey Till. Vadose Zone Journal 3 (2): 634644. https://doi.org/10.2136/vzj2004.0634.

Mosthaf, K., B. Brauns, A. S. Fjordbøge, M. M. Rohde, H. Kerrn-Jespersen, P. L. Bjerg, P. J. Binning and M. M. Broholm. 2018. Conceptualization of Flow and Transport in a Limestone Aquifer by Multiple Dedicated Hydraulic and Tracer Tests. Journal of Hydrology 561: 532-46. https://doi.org/10.1016/j.jhydrol.2018.04.011.

Muniruzzaman, M., C. M. Haberer, P. Grathwohl and M. Rolle. 2014. Multicomponent Ionic Dispersion during Transport of Electrolytes in Heterogeneous Porous Media: Experiments and Model-Based Interpretation. Geochimica et Cosmochimica Acta 141: 656-69. https://doi.org/10.1016/j.gca.2014.06.020.

Muniruzzaman, M. and M. Rolle. 2016. Modeling Multicomponent Ionic Transport in Groundwater with IPhreeqc Coupling: Electrostatic Interactions and Geochemical Reactions in Homogeneous and Heterogeneous Domains. Advances in Water 
Resources 98: 1-15. https://doi.org/10.1016/j.advwatres.2016.10.013.

Neuman, S. P. 2005. Trends, Prospects and Challenges in Quantifying Flow and Transport through Fractured Rocks. Hydrogeology Journal 13: 124-47. https://doi.org/10.1007/s10040-004-0397-2.

O’Hara, S. K., B. L. Parker, P. R. Jørgensen and J. A. Cherry. 2000. Trichloroethene DNAPL Flow and Mass Distribution in Naturally Fractured Clay: Evidence of Aperture Variability. Water Resources Research 36 (1): 135-47. https://doi.org/10.1029/1999WR900212.

Pankow, J. F. and J. A. Cherry. 1996. Dense Chlorinated Solvents and Other DNAPLs in Groundwater: History, Behavior, and Remediation. Waterloo Press.

Parker, B. L., D. B. McWorther and J. A. Cherry. 1997. Diffusive Loss of Non-Aqueous Phase Organic Solvents from Idealized Fracture Networks in Geologic Media. Ground Water 6 (35): 1077-88.

Parkhurst, D. L. and L. Wissmeier. 2015. PhreeqcRM: A Reaction Module for Transport Simulators Based on the Geochemical Model PHREEQC. Advances in Water Resources 83: 176-89. https://doi.org/10.1016/j.advwatres.2015.06.001.

Rolle, M., G. Chiogna, D. L. Hochstetler and P. K. Kitanidis. 2013a. On the Importance of Diffusion and Compound-Specific Mixing for Groundwater Transport: An Investigation from Pore to Field Scale. Journal of Contaminant Hydrology 153: 5168. https://doi.org/10.1016/j.jconhyd.2013.07.006.

Rolle, M. and P. K. Kitanidis. 2014. Effects of Compound-Specific Dilution on Transient Transport and Solute Breakthrough: A Pore-Scale Analysis. Advances in Water 
Resources 71: 186-99. https://doi.org/10.1016/j.advwatres.2014.06.012.

Rolle, M., M. Muniruzzaman, C. M. Haberer and P. Grathwohl. 2013b. Coulombic Effects in Advection-Dominated Transport of Electrolytes in Porous Media: Multicomponent Ionic Dispersion. Geochimica et Cosmochimica Acta 120: 195-205. https://doi.org/10.1016/j.gca.2013.06.031.

Rosenbom, A. E., P. J. Binning, J. Aamand, A. Dechesne, B. F. Smets and A. R. Johnsen. 2014. Does Microbial Centimeter-Scale Heterogeneity Impact MCPA Degradation in and Leaching from a Loamy Agricultural Soil? Science of the Total Environment 472: 90-98. https://doi.org/10.1016/j.scitotenv.2013.11.009.

Rosenbom, A. E., V. Ernstsen, H. Flühler, K. H. Jensen, J. C. Refsgaard and H. Wydler. 2008. Fluorescence Imaging Applied to Tracer Distributions in Variably Saturated Fractured Clayey Till. Journal of Environmental Quality 37 (2): 448-58. https://doi.org/Doi 10.2134/Jeq2007.0145.

Rosenbom, A. E., R. Therrien, J. C. Refsgaard, K. H. Jensen, V. Ernstsen and K. E. S. Klint. 2009. Numerical Analysis of Water and Solute Transport in Variably-Saturated Fractured Clayey Till. Journal of Contaminant Hydrology 104: 137-52. https://doi.org/10.1016/j.jconhyd.2008.09.001.

Sihota, N., B. McAlexander, M. Lyverse and K. U. Mayer. 2018. Multi-Year CO2 Efflux Measurements for Assessing Natural Source Zone Depletion at a Large HydrocarbonImpacted Site. Journal of Contaminant Hydrology 219 (March): 50-60. https://doi.org/10.1016/j.jconhyd.2018.10.007.

Snow, D. T. 1969. Anisotropic Permeability of Fractured Media. Water Resources 
Research 5 (6): 1273-89.

Wang, L., M. B. Cardenas, D. T. Slottke, R. A. Ketcham and J. M. Sharp Jr. 2015. Modification of the Local Cubic Law of Fracture Flow for Weak Inertia, Tortuosity, and Roughness. Journal of the American Water Resources Association 51: 2064-80. https://doi.org/10.1111/j.1752-1688.1969.tb04897.x.

Werth, C. J., C. Zhang, M. L. Brusseau, M. Oostrom and T. Baumann. 2010. A Review of Non-Invasive Imaging Methods and Applications in Contaminant Hydrogeology Research. Journal of Contaminant Hydrology 113 (1-4): 1-24. https://doi.org/10.1016/j.jconhyd.2010.01.001.

Wildenschild, D., K. H. Jensen, K. Villholth and T. H. Illangasekare. 1994. A Laboratory Analysis of the Effect of Macropores on Solute Transport. Ground Water 32 (3): 38189.

Ye, Y., G. Chiogna, O. Cirpka, P. Grathwohl and M. Rolle. 2015. Experimental Investigation of Compound-Specific Dilution of Solute Plumes in Saturated Porous Media: 2-D vs. 3-D Flow-through Systems. Journal of Contaminant Hydrology 172: 33-47. https://doi.org/10.1016/j.jconhyd.2014.11.002.

Yu, R., R. G. Andrachek, L. G. Lehmicke, A. A. Pierce, B. L. Parker, J. A. Cherry and D. L. Freedman. 2018. Diffusion-Coupled Degradation of Chlorinated Ethenes in Sandstone: An Intact Core Microcosm Study. Environmental Science \& Technology, acs.est.8b04144. https://doi.org/10.1021/acs.est.8b04144. 
Figure 1: Illustration of the main elements of the LUC setup. The inset shows the prefabricated polyurethane membrane with filled solidified polyurethane preventing flow along the column rim.

Figure 2: LUC sampling. (a) Cutting shoe and sampling cylinder, which is continuously pressed down vertically by adding weights on top. (b) Final shape of the column, before it is installed within the flexible membrane. (c) Column inside the polyurethane membrane; rim flow is prevented by filling a polyurethane fluid along the column rims. (d) Removal of the column in a split transport cylinder.

Figure 3: Example of hydraulic test in an LUC subjected to different hydraulic gradients.

Figure 4: (a) Setup and geometry of the LUC discrete-fracture model with three equidistant vertical fractures and four inlet and outlet ports at the bottom and top of the setup, respectively. Arrows indicate the location of the four outlet ports. (b) - (f) Simulated evolution of the concentration in the LUC experiment from Jørgensen et al. (2004a) at different times. Tracer injection stopped after 6.7 days.

Figure 5: Measured breakthrough from Jørgensen et al. (2004a) compared with the results of the 3-D numerical simulations. (a) Tracer injection and flushing with constant flow rate; (b) tracer injection with variable flow rate and constant tracer concentration.

Figure 6: Simulated tracer breakthrough curves at different flow rates plotted as functions of effluent volume. 


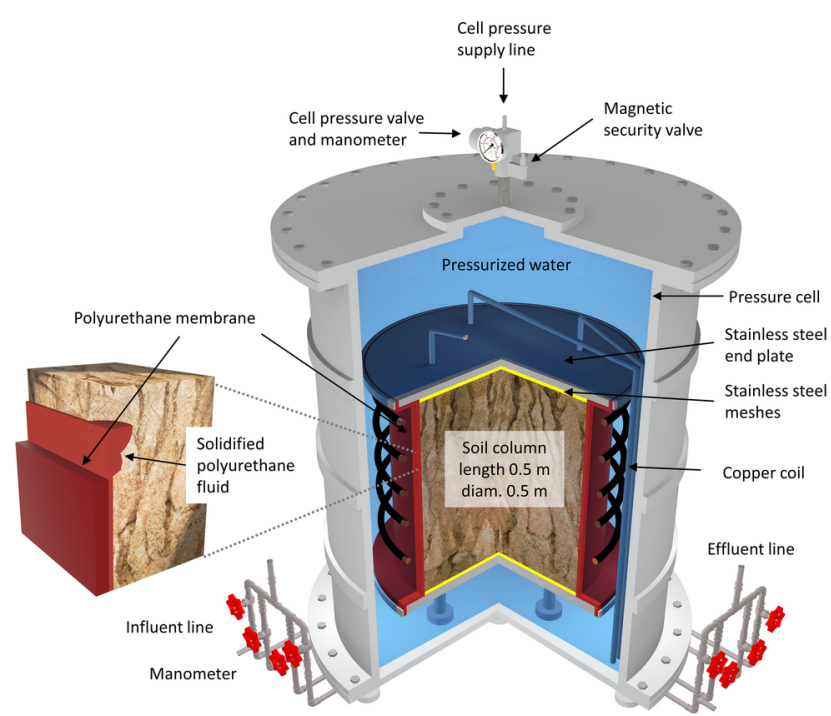

GWAT_12885_GWAT_12885_Figure1 2(2).tif

This article is protected by copyright. All rights reserved. 


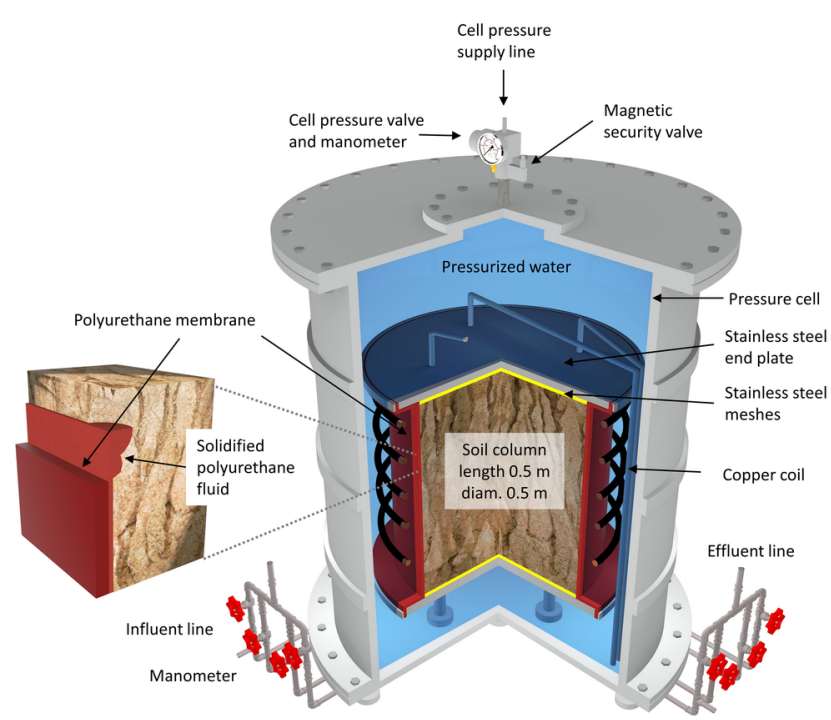

GWAT_12885_GWAT_12885_Figure1 2.tif

This article is protected by copyright. All rights reserved. 


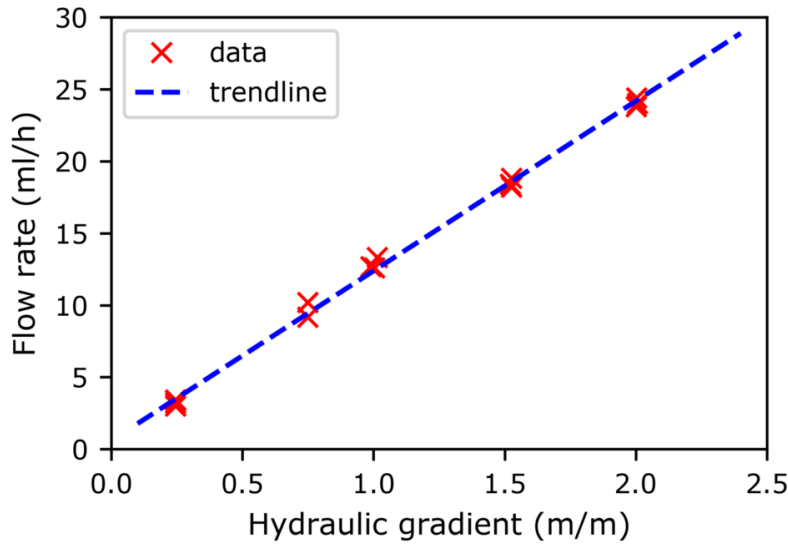

GWAT_12885_GWAT_12885_Figure3.tif

This article is protected by copyright. All rights reserved. 


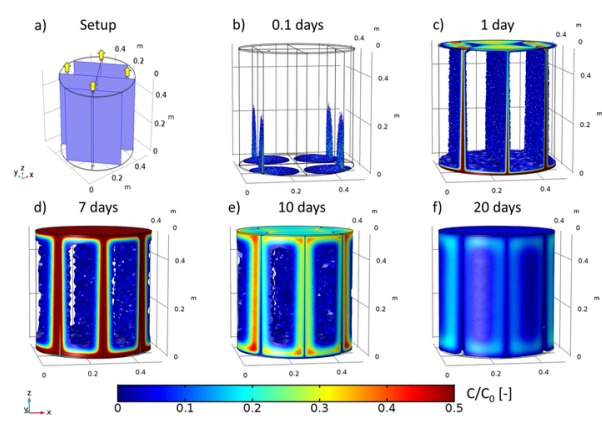

GWAT_12885_GWAT_12885_Figure4.tif 

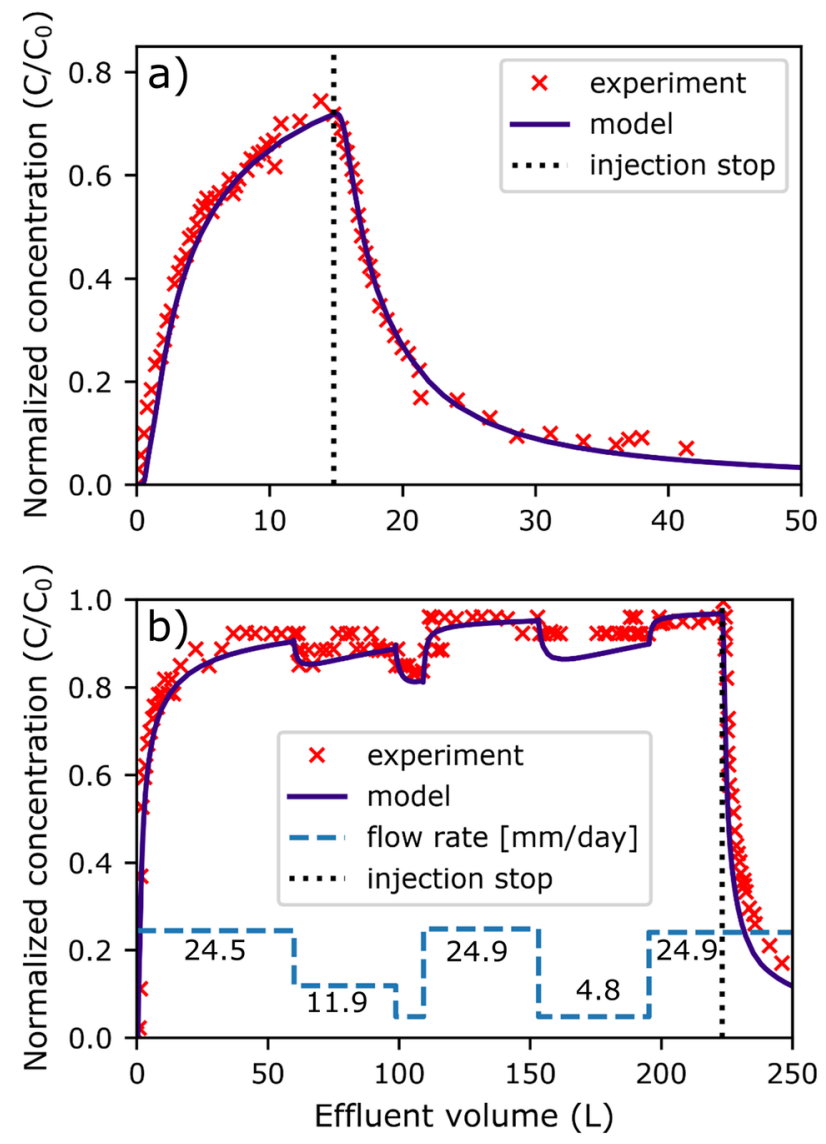

GWAT_12885_GWAT_12885_Figure5.tif 


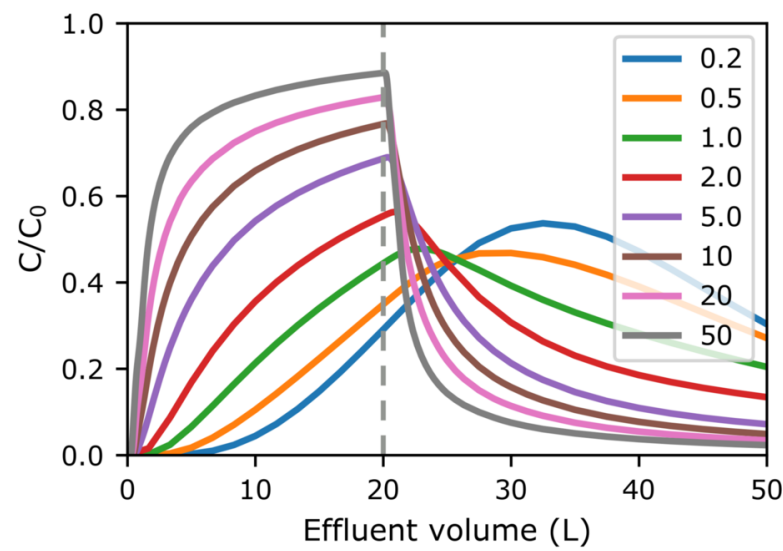

GWAT_12885_GWAT_12885_Figure6.tif 